\title{
INTERACTIVE TECHNOLOGY OF TEACHING AS A FACTOR FOR THE DEVELOPMENT OF FOREIGN LANGUAGE DIALOGICAL SPEECH
}

\author{
Serdyuchenko Yuliia Oleksandrivna, \\ $\mathrm{PhD}$ researcher \\ Zaporizhzhia national university \\ virus.net@ukr.net \\ orcid.org/0000-0002-5018-7833
}

\begin{abstract}
The article deals with the use of interactive technologies for teaching foreign language dialogical speech of senior secondary school pupils. The object of study is the dialogical speech in the teaching of senior pupils, and the subject is the use of interactive technologies in teaching foreign language dialogical speech of senior pupils. The aim of this article is to consider and justify the effectiveness of the use of interactive technologies in teaching senior secondary school pupils for foreign language dialogical speech. Interactive teaching is a kind of activity that involves the interaction of a pupil with the educational environment, serves as a source of experience acquired by them, in other words, it is the cooperation of subjects of pedagogical interaction. Teacher sets the educational target of the lesson and organizes, directs the interests of a pupil, the level of their knowledge and skills, i.e. realizes the subject subject principle of teaching. The use of interactive learning technologies is a good basis for the formation of foreign language communication skills, in particular dialogical skills and abilities of pupils, since such teaching forms three main groups of skills: communicative (ability to express their opinions clearly, to justify, to give arguments, to analyze other thoughts); perception (the ability to listen and correctly perceive information, to understand the mood and emotional state of the interlocutor, to refelect and think about information); interactive (to express thoughts, discuss information, conduct interviews with questions and requirements formulation, etc.). In order to facilitate learning through the use of interactive technologies, scientists and teachers offer the following techniques: informational interactive techniques (dialogical interaction of students, in which there is an exchange of material or spiritual values); cognitive interactive techniques (interaction of students in order to obtain new knowledge, information, for example, role-playing game "Brain storming"); motivational interactive techniques (dialogical interaction of pupils, where they determine the ways of group activities and themselves); regulatory interactive techniques (pupils set certain rules for their dialogical interaction).
\end{abstract}

Key words: interaction, interactive teaching, interactivity, interactive technologies, subject-subject principle, dialogical speech.

\section{ІНТЕРАКТИВНІ ТЕХНОЛОГІЇ НАВЧАННЯ ЯК ФАКТОР РОЗВИТКУ ІНШОМОВНОГО ДІАЛОГІЧНОГО МОВЛЕННЯ СТАРШОКЛАСНИКІВ}

\author{
Сердюченко Юлія Олександрівна, \\ аспірант \\ Запорізький національний університет \\ virus.net@ukr.net \\ orcid.org/0000-0002-5018-7833
}

\begin{abstract}
У статmі розглядається використання інтерактивних технологій навчання іншомовного діалогічного мовлення старшокласників середньої загальноосвітньої школи. Об'єкт дослідження - діалогічне мовлення у навчанні старшокласників, а предмет - застосування інтерактивних технологій у навчанні іншомовного діалогічного мовлення старшокласників. Метою цієї статmі є розгляд та обгрунтування ефективності використання інтерактивних технологій у навчанні старшокласників середньої загальноосвітньої школи іншомовного діалогічного мовлення. Інтерактивне навчання - вид діяльності, що передбачає взаємодію учня з навчальним середовищем, слугує джерелом засвоюваного ним досвіду, іншими словами, че співпраця суб'єктів педагогічної взаємодії. За такої форми навчання в центрі навчального процесу знаходяться учень, його мотиви, цілі та неповторний психологічний склад, тобто учень як особистість. Вчитель встановлює навчальну мету уроку й організовує, направляє інтереси учня, рівень його знань і вмінь, тобто реалізує суб'єкт суб'єктний принцип навчання. Використання інтерактивних технологій навчання є сприятливим підгрунтям для форммвання іншомовних комунікативних, зокрема діалогічних, навичок та вмінь учнів, адже таке навчання формує три основних групи вмінь: комунікативні (вміння ясно і чітко висловлювати свою думку, обгрунтовувати, наводити аргументи, аналізувати інші думки); сприйняття (вміння слухати і правильно сприймати інформацію, розуміти настрій та емоційний стан співбесідника, мислити та обмірковувати інформацію); інтерактивні (висловлювати думки, обмірковувати та обговорювати інформацію, вести бесіду із запитаннями та формулюванням вимог тощо). 3 метою полегшення навчання під час застосування інтерактивних технологій вчені-педагоги пропонують такі
\end{abstract}


прийоми: інформаційні інтерактивні прийоми (діалогічна взаємодія учнів, за якої відбувається обмін матеріальними чи духовними цінностями); пізнавальні інтерактивні прийоми (взаємодія учнів із метою отримання нових знань, інформації, наприклад, рольова гра «Мозковий штурм»); мотиваційні інтерактивні прийоми (діалогічна взаємодія учнів, де вони самі визначають способи групової діяльності та самих себе); регулятивні інтерактивні прийоми (учні встановлюють певні правила своєї діалогічної взаємодії) тощо. Застосування у навчальному процесі з іноземної мови таких прийомів, як, наприклад, «Круглий стіл», "Ток шоу», «Метаплан», "Дебати» тощо, не тільки робить урок цікавим, а і залучає учнів до активного спілкування та взаємодії з іншими учнями, спонукає до вирішення проблемних питань та пошуку необхідної інформації.

Ключові слова: інтерактив, інтерактивне навчання, інтеракція, інтерактивні технології, суб'єкт суб'єктний принцип, діалогічне мовлення.

\section{Introduction}

According to the national strategy for the development of education in Ukraine up to 2021, and taking into account the current social and economic changes in Ukraine and the development of international relations, it is expedient to introduce European standards into the system of foreign language education in Ukraine, as well as the formation of the readiness of students of secondary schools to the future foreign language communication. Consequently, education faces issues that require not only the attraction of new goals to the process of teachng foreign languages, but also the application of new forms and means. The active use of interactive technologies in foreign language lessons indicates to unconditional changes in the content of education.

The aim of this article is to consider and justify the effectiveness of the use of interactive technologies in teaching senior secondary school pupils for foreign language dialogical speech.

The object of the study is dialogical speech in teaching senior pupils for foreign communication. The subject of the study is the use of interactive technologies in the teaching of foreign language dialogical speech of senior pupils.

\section{The concepts of "interaction" and "interactive teaching"}

Effectiveness of the use of interactive teaching technologies and their pedagogical potential as a means of forming communicative competence has been determined and grounded by such scientists as V.Redko (2011), S. Kashlev (2005), O. Lipchanko-Kovachiko (2016), S. Nakhod (2014 ), L. Pirozhenko (2004), O. Pometun (2004) and others. Scientists have explored the benefits of using interactive technologies while teaching foreign languages, as well as the need to implement them in the educational space of secondary schools.

The problem of using interactive teaching technologies in a secondary school is covered by scientista in various aspects, such as the substantiation of the concept and methods of interactive teaching (Кашлев, 2005), the specifics of the use of interactive technologies (Мельник, 2006), etc. Scientists and teachers define the term "interaction" as the ability to interact (Кашлев, 2005), the presence of feedback between a teacher or a means of teaching and pupils (Щукин, 2000). In this work, interaction is considered to be a two-way contact between the puil as the subject of study, on the one hand, and with the object / subject of study, on the other hand, that may be another pipil, teacher or any means of study. The scientist, V. Melnyk, defines the term "interactivity" as a learning process in the context of a dialogue, during which the cooperation of its participants takes place (Мельник, 2006). Interactive teaching is a cooperation of subjects of pedagogical interaction (Липчанко-Ковачико, 2016); the type of activity that involves the interaction of the pupil with the educationl environment, serves as a source of experience gained by them (Пометун, 2007).

This form of educational process gives pupils the opportunity to be "active participants in interpersonal interaction" (Липчанко-Ковачико, 2016: 34), students do not act as observers or listeners, but take an active part in the educational process, thus creating an interactive environment (Пометун, 2004), and the teacher only stimulates and inspires students to further independent actions on the way to achieving the identified educational goals (Редько, 2011). Consequently, in the center of the educational process is a pupil, their motives, goals and unique psychological composition and personality. The teacher sets the educational goal of the lesson and organizes, directs the interests of a pupil, the level of their knowledge and skills.

Accepting the definition of the concept of "interactivity" as "cooperation", which is the essence of interactive learning technologies, in the context of teaching foreign languages, this "cooperation" is defined as the interpersonal foreign communication of participants, that is, the educaional process acquires dialogicity, which "characterizes interactive technologies as technologies of cooperation of subjects of pedagogical interaction" (Липчанко-Кова- 
чико, 2016: 32). In other words, there is a joint interaction between the teacher and the pupil. During such interaction between the teacher and the pupil (pupils) there is an interpersonal contact, the participants are united by the common goal and expected result (Липчанко-Ковачико, 2016), where the teacher, as the subject of their pedagogical activity, plans, coordinates and adjusts pupils' actions, inducing them to become the subject of their own educational and cognitive activity (Наход, 2007). Such a type of activity in the modern teaching of foreign languages is called "student centered approach" (Редько, 2011: 28-29), which implies the transfer of the initiative to the pupil, as well as the encouragement of pupils to teamwork, work in pairs and groups (Щукин, 2000). All these factors undoubtedly contribute to the successful realization of personal oriented, activity, and especially communicative approaches while learning a foreign language by pupils. Thus, in the practice of teaching foreign languages, the use of interactive technologies is associated with the ability of participants to interact in the educational process, during which there is no predominance of any participant over others (Редько, 2011), the teacher no longer holds the active position of the "commander-in-chief" in the educational process, but only corrects the actions of pupils and promotes the pupils' initiative and activity during the educational process.

Teaching senior pupils involves a radical reorganization of the content and methods of teaching, as well as the maximum consideration of individual characteristics and interests of pupils, because senior pupils' interest in school and studying significantly increases, since the study acquires directly life-related content connected with the future. This means that the teacher cannot but take into account that, like any activity, communicative activity is one of the cognitive needs of a pupil, as well as the ability to express and substantiate their thoughts. The use of interactive methods, namely conversations, dialogues, discourses, etc., promotes the development of critical thinking among pupils, which can be defined as the leading intellectual activity of pupils in a communicative interaction (Редько, 2011). Participation in simulated situations, especially when they are as close as possible to real life and correspond to life experience and knowledge of senior pupils, stimulate participants in the communicative process not only to fulfill their role, but also to share their thoughts, to show a personal attitude to the topics discussed, to formulate their own judgment and to defend their own looks (Kuzmenko, Serdyuchenko, 2018: 209-210).

According to O. Pometun, passive teaching, when the teacher is in the "center of attention", and the pupil is only a listener, in such a study "the pupil is $<\ldots>$ without questions, without interest, without being interested in the results. When studying is active, the pupil is constantly in a state of search, wants to get an answer to the questioneeds information to solve the issue"(Пометун, 2004: 15).

Thus, a conclusion can be made that the active mode of study is the most attractive for a modern senior school pupil, because due to being active during the lesson of a foreign language, the pupil acquires exactly the practical knowledge that, in their opinion, will help them in the future when communicating at the professional and everyday levels.

The use of interactive learning technologies is a good basis for the formation of foreign language communication skills, in particular dialogical skills and abilities of pupils, since such training, according to $\mathrm{O}$. Pometun, requires a multilateral type of interaction and communication (Пометун, 2007). Consequently, dialogue is the communication of two or more people, their interaction during which they exchange thier thoughts and information. In order to successfully develop the dialogical communicative skills of senior pupils, the educational process shall reflect the subject - subject principle of interaction, the essence of which is to create a purposeful pair, group or intergroup activity of the subjects, feedback and achieve mutual understanding between the participants of the oral foreign language communication. Under the conditions of an interactive foreign language course, the possibility of creating a supportive communicative environment arises through the use of forms, methods and means of interactive technologies that could motivate pupils to demonstrate initiative while performing their tasks (Липчагко-Ковачико, 2016: 56).

In her work, O.V. Lipchanko-Kovachiko (2016) determines that the use of interactive technologies facilitates the development of three main groups of pupils' skills:

1) communicative (the ability to clearly express their opinions, to justify, to give arguments, to analyze other thoughts);

2) perception (the ability to listen and correctly perceive information, to understand the mood and emotional state of the interlocutor, to reflect and think about information);

3 ) interactive (to express thoughts, discuss information, conduct interviews with questions 
and requirements formulation, etc.) (Липчанко-Ковачико, 2016).

\section{Methods of teaching with interactive} technologies

According to the foreign language programme for secondary schools, pupils at the end of the 11th year should understand clearly articulated speech when they are addressed in everyday situations; enter the conversation in a familiar topic without preparation; can express surprise, sadness, joy, indifference and react in a certain way to similar feelings; express their thoughts and views and ask about the opinion of their interlocutor; politely express their convictions, opinions, consents and disagreements, etc. (HПІМ, 2017). Agreeing with the researches of the scientists, the achievement of such goals, immersing a student in an artificial linguistic and cultural environment, is possible through the use of interactive technologies and dialogical speech.

Scientists and teachers offer a number of techniques to facilitate learning through the use of interactive technologies: informational interactive techniques (dialogical interaction of pupils, in which exchange of material or spiritual values takes place); cognitive interactive techniques (interaction of pupils in order to obtain new knowledge, information, for example, roleplaying game "Brain storming"); motivational interactive techniques (dialogical interaction of pupils, where they determine the ways of group activities and themselves. As an example, the "Self-assessment" method, during which pupils analyze the positive and negative aspects of their activities regarding their work in the group, can be referred to as an example); regulatory interactive techniques (pupils set certain rules for their dialogical interaction, for example, "We will make rules") (Пометун, 2007).

In order to consider interactive teaching technologies in more detail, the following techniques that are widely used in teaching dialogical speech for senior pupils can be defined, namely:

1) "Round table" - pupils exchange opinions in small groups (Пометун, Піроженко, 2004);

2) "Expert group committee"- joint discussion of a problem or report (Липчанко-Ковачико, 2016);

3) "Disputes"-joint discussion of the speeches of the participants from two opposing teams, the nomination of consent and objection (Пометун, Піроженко, 2004);

4) "Aquarium" - group type of work on the discussion of the problems raised (Пометун, Піроженко, 2004);
5) "Talk show" - involvement of students in acquiring skills of public speaking (Пометун, Піроженко, 2004);

6) «Metaplan»-set of elements of «Brain storming», analysis of cases, games (Пометун, Піроженко, 2004);

7) "Chain" - pupils build expressions at the sentence level, the rest in turn logically supplements it (Пометун, 2007);

8) "Microphone" - pupils have the opportunity to say something in turns expressing their opinion or answering questions (Пометун, Піроженко, 2004);

9) "PRES method" - pupils give arguments and substantiate their rightness to a controversial issue (Пометун, Піроженко, 2004);

10) "Take the position" - after the teacher reads the statement, pupils take a position near the poster "Yes" or "No", and then they give arguments regarding their position (Пометун, 2007).

\section{Conclusions}

Interactive technologies can be used to teach senior pupils for dialogical speech, as they promote the development of foreign language communication skills, as well as the process of teaching foreign language speech in particular. Lessons involving interactive technologies capture and motivate students, as well as increase their interest in further learning a foreign language. Effective use of interactive technologies when teaching dialogical speech requires its gradual introduction into the educational process, especially when pupils are unfamiliar with similar teaching methods, since interactive cooperation requires a certain change in the life of the whole class. It is necessary to begin with the gradual inclusion of elements of this model, using simple interactive technologies, such as group work or pair work, "Brain storming". The use of interactive technologies in foreign language lessons is not the main goal, as it is only an auxiliary tool that promotes the creation of an educational atmosphere that would enable the implementation of personality oriented teaching approach and encourage pupils to collaborate and interact, as well as the manifestation of initiative, autonomy and self-realization while studying.

\section{BIBLIOGRAPHY:}

1. Кашлев С.С. Технология интерактивного обучения. Минск : Беларусский верасень, 2005. 196 с.

2. Липчанко-Ковачико О.В. Підготовка майбутніх бакалаврів-філологів до використання інтерактивних технологій у профресійній діяльності : дис. .... канд. пед. наук : 13.00.04 ; Нац. університет водного господарства та природокористування. Рівне, 2016. 300 с. 
3. Мельник В.В. Інтеракція в освітньому процесі: технологія організації. Управління школою. 2006. № 13. С. 15-34.

4. Миркович І.Л. Інтегроване навчання англійського діалогічного мовлення учнів 4-х класів на основі драматизації автентичних казок : дис. ... канд. пед. наук : 13.00 .02 ; Південноукраїнський нац. пед. ун-т ім. К.Д. Ушинського. Одеса, 2017. 325 с.

5. НПІМ: Навчальні програми з іноземних мов для загальноосвітніх навчальних закладів і спеціалізованих шкіл за поглибленим вивченням іноземних мов (10-11 класи). Київ, 2017. 72 c. URL: https://mon.gov.ua/storage/app/media/zagalna\%20 serednya/programy-10-11-klas/2018-2019/inozemnimovi-10-11-19.09.2017.pdf (дата звернення: 28.04.2019).

6. Наход С.А. Педагогічна взаємодія як базисна категорія інтерактивного навчання. Наукові записки Тернопільського національного педагогічного університету імені Володимира Гнатюка. Серія «Педагогіка». 2014. № 12. С. 23-29.

7. Пометун О.І. Енциклопедія інтерактивного навчання. Київ, 2007. 144 с.

8. Пометун О.І., Піроженко Л.В. Сучасний урок. Інтерактивні технології навчання. Київ : А.С.К., 2004. 192 с.

9. Редько В.Г. Інтерактивні технології навчання іноземної мови. Рідна мова. 2011. № 8-9. С. 28-36.

10. Щукин А.Н. Лингводидактический энциклопедический словарь. Москва : Астраль ; АСТ ; Хранитель, 2000. 746 с.

11. Charles D., Kusanagi Y. Using drama to motivate EFL students: Building classroom communities and student identities. Journal of Asian Language Teaching. Tokyo : JALT, 2007. P. 606-613.

12. Kuzmenko A.O., Serdyuchenko Yu.O. Language teaching and forming of oral communication skills through role play. Philological sciences: development prospects in countries of Europe at the beginning of the third millennium : Collective monograph. Riga: Baltija Publishing, 2018. P. 207-226.

\section{REFERENCES:}

1. Kashlev, S.S. (2005). Tekhnologiya interactivnogo obucheniya [Interactive teaching technology]. Minsk: Belarusskiy verasen [in Russian].

2. Lipchanko-Kovachiko, O.V. (2016). Pidgotovka maibutnikh bakalavriv-philologiv do vykorystannya interactyvnykh tekhnologiy u profesiyniy diyalnosti [Preparation of future bachelor philologists for using interactive technologies in professional activity] (Candidate's thesis). Rivne: Nats. universitet vodnogo gospodarstva ta pryrodokorystuvannya [in Ukrainian].

3. Melnyk, V.V. (2006). Interactsiya v osvitnyomu protsesi: tekhnologiya organizatsii [Interactivity in educational process: technology of organization]. Upravlinnya shkoloyu [School management], no. 13, pp. 15-34 [in Ukrainian].

4. Myrkovych, I.L. (2017). Integrovane navchannya dialogichnogo movlennya uchniv 4-kh klasiv na osnovi dramatyzatsii avtentychnykh kazok [Integrative teaching of dialogical speech for pupils of the forth form on the basis of authentic fairy tails] (Candidate's thesis). Odesa: Pivdennoukrainsliy nats. ped. un-t im. K.D. Ushinskogo [in Ukrainian].

5. (2017). NPIM: Navchalni program z inozemniyi movy dlya zagalnoosvitnikh navchalnykh zakladiv I spetsializovanukh shkil za poglyblennym vyvchennyam inozemnykh mov (10-11 klasy) [Foreign language curricula for secondary schools and specialized schools for in-depth study of foreign languages (10-11 grades)]. Kyiv Retrieved from: https://mon.gov.ua/storage/app/media/zagalna $\% 20$ serednya/programy-10-11-klas/2018-2019/inozemnimovi-10-11-19.09.2017.pdf [in Ukrainian].

6. Nakhod, S.A. (2014). Pedagogichna vzayemodiya yak bazysna kategoriya interaktyvnogo navchannya [Pedagogical interaction as a basic category of interactive teaching]. Naukovi zapysky Ternopilskoho natsionalnoho pedahohichnoho universytetu imeni Volodymyra Hnatiuka. Seriia "Pedagogika", no. 12, pp. 23-29 [in Ukrainian].

7. Pometun, O.I. (2007). Entsiklopediya interactvnogo navchannya [Encyclopedia of interactive teaching]. Kyiv [in Ukrainian].

8. Pometun, O.I., Pirozhenko, L.V. (2004). Sucvhasnyi urok. Interactyvni tekhnologii navchannya [Contemporary lesson. Interactive Teaching Technologies]. Kyiv: A.S.K. [in Ukrainian].

9. Redko, V.H. (2011). Interaktyvni tekhnologii navchannya inozemnoyi [Interactive technologies of foreign language teaching]. Ridna mova [Native language], no. 8-9, pp. 28-36 [in Ukrainian].

10. Shchukin, A.N. (2000). Lingvodidakticheskiy entsiklopedicheskiy slovar [Linguo-didactic encyclopaedic dictionary]. Moscow: Astral; AST; Khranitel [in Russian].

11. Charles, D., Kusanagi, Y. (2007). Using drama to motivate EFL students: Building classroom communities and student identities. Journal of Asian Language Teaching. Tokyo: JALT, pp. 606-613 [in English].

12. Kuzmenko, A.O., Serdyuchenko, Yu.O. (2018). Language teaching and forming of oral communication skills through role play. Philological sciences: development prospects in countries of Europe at the beginning of the third millennium: collective monograph. Riga: Baltija Publishing, pp. 207-226 [in English]. 